VOL. 01 NO. 02, December 2019

\title{
Multimedia Development of English Learning for Recount Text Materials
}

\author{
Mochlis Ekowijayanto \\ Universitas Nurul Jadid \\ mochliseko@unuja.ac.id
}

\begin{abstract}
In this study aims to: (1) produce English learning multimedia products for recount text material, (2) find out the feasibility of English learning multimedia products for recount text material, and (3) find out the effectiveness of English learning multimedia multimedia products for recount text material for class VIII students at SMPNJ. This research method is a research and development (R\&D) taken from the Alessi and Trollip model which consists of three stages, namely: (1) planning, (2) design, and (3) development. Data collection through observation, interviews, questionnaire sheets, and tests. Then, the data obtained were analyzed descriptively quantitatively. The effectiveness of the product was analyzed using the $\mathrm{N}$-gain formula (normalized learning outcomes). The results of the study are as follows. (1) the products produced are multimedia in the form of English learning CDs for recount text material consisting of instructions, Competency Standards and Basic Competencies (SK and KD), description of material, summary, quiz, and evaluation; (2) the product developed is suitable for use as a complementary medium for learning English for recount text learning; (3) an increase in the average score of all students from the pretest and posttest results of $0.90(\mathrm{~N}$-gain $\geq 0.7)$. This means that the effectiveness of the product being developed is in the high category

Keywords: Multimedia development, Recount Text, SMP Nurul Jadid Paiton
\end{abstract}

\section{INTRODUCTION}

Learning English is very important because English is a global language that is used internationally. In learning English, learning must be effectively carried out. Teachers can use teaching aids to attract students' attention. Patel and Jain mention there are three kinds of teaching aids, namely visual aids, audio and audio visual. The teaching aids can be chosen by the teacher to suit the language skills (reading, listening, speaking, writing) to be taught (Patel \& Jain, 2008). Visual aids such as pictures have the benefit of being able to convey meaning and be able to attract the attention of students (D'Arcy Nell, 2017). Audio aids can improve listening skills. Audio visual aids can increase student attention and motivation because through these aids both students' eyes and ears become active (Patel \& Jain, 2008).

Multimedia is expected to be a teaching aid that will make learning effective because multimedia is a combination of visual, audio and audio visual elements; such as images, text, sound, animation, and video. Multi-media is a combination of text, images, sound, animation, and video delivered through computer devices, electronics, or other digital engineering tools. Therefore, multimedia learning is very important to be developed so that English learning becomes effective. Furthermore, the use of multimedia approach enhances teaching and learning experience in architecture design studios (Ezennia, Agbonome, Uwajeh, \& Iyendo, 2016).

Multimedia learning as learning from words and pictures, and we define multimedia instruction as presenting words and pictures that are intended to foster learning (Curir, de Romeri, \& Murante, 2010). Multimedia are aid tools which are necessary for English learning. Multimedia can be used to help to simplify learning process of language and perfect it, reduce the use of mother tongue or first language, arouse students' learning motivation and interest, explain new concept in order that students can understand without difficulties and misunderstanding (Baidawi, 2016). 


\section{VOL. 01 NO. 01, DECEMBER 2019}

SMP Nurul Jadid Paiton is an Islamic school with very good and complete facilities but it has not been utilized optimally. Based on observations on November 9, 2018, the facilities owned were a computer laboratory with 36 computer units and flat screen monitors. The computer in the laboratory has the specifications of a Pentium Dual Core processor, 1 GB DDR RAM, and Opera-Windows System 7. In addition, each class has an LCD projector that can be used by the teacher to teach. Weaknesses in these schools are learning English class VIII by using a multimedia learning program that has never existed. Thus, this school has potential that can be developed, especially the use of multimedia learning programs for learning English.

The English material that is very difficult for students to study at SMP Nurul Jadid Paiton is recount text material. This is evidenced from the students 'daily test scores on the recount text material which are still below the Minimum Completion Criteria (KKM) when compared to the students' daily test scores on other text materials such as functional texts, and descriptive texts. The minimum value of completeness criteria that has been determined is 75 . In the daily test of recount text material in class VIII E, students who get grades below the KKM score are eight students, students who get the same value as KKM scores are seven students, while students who get grades above the KKM score of eight students. In the daily tests of functional text material in class VIII E, none of the students got grades below the KKM grade. There are seven students who get the same grade as the KKM. Students who scored above the KKM score totaled 16 students. In the daily test of descriptive text material in class VIII E, students who received grades below the KKM score were three students, students who received grades equal to the KKM score were two students, and students who scored above the KKM value were 18 students. Recount text is a type of text about a story, action, or activity. Its purpose is to entertain or inform the reader. This type of text uses the past tense form with past verbs to tell someone's experience in the past. This text material was taught to students of class VIII in semester 1. Based on the results of interviews conducted on November 9, 2018 with English teachers in class VIII E, recount text material is difficult material for students. Difficulties faced by students according to the teacher are students having difficulty in arranging a series of events or stories in the form of random paragraphs from the recount text. Furthermore, students still do not understand the changes in past verb forms in the recount text and also the vocabulary students have a little. After getting the information from the teacher, the survey was conducted on November 19, 2018 with 23 students of class VIII E SMP Nurul Jadid Paiton to complete the information. Based on the survey, it can be seen that 23 students have difficulty arranging random recount paragraphs, 20 students out of 23 students have difficulty turning present verbs into past verbs, and 23 students have difficulty arranging random words into 1 sentence intact. The results of the survey also showed that the students' vocabulary mastery was lacking which was seen when 23 students found it difficult to compile random recount text paragraphs, 20 students out of 23 students found it difficult to change present verbs to past verbs such as sell to sell and selled, am become amed, buy (buy) become buyed and buying, are being was, where, when and ared, and 23 students still have difficulty stringing random words into 1 whole sentence which is proven when students are only able to string the sentence I was.

Most students love learning with music. The results of the survey showed that 17 students liked learning to be accompanied by music, five students liked learning not to be accompanied by music, and one student did not answer questions about the joy of learning accompanied by music in the survey questionnaire. Therefore, multimedia learning with musical accompaniment is expected to help students who have a hobby of learning accompanied by music to learn English recount text material. Music is useful for entertaining and can connect very well with a relaxed environment and learning environment in the classroom (Harmer, 1991). 
VOL. 01 NO. 01, DECEMBER 2019

\section{METHOD}

Research carried out is included in research and development (Research and Development). The results of this study are multimedia English learning products for recount text learning for class VIII students at SMP Nurul Jadid Paiton, which were made using Adobe Flash CS5 and other supporting programs.

The model of developing multimedia learning in this study refers to Alessi and Trollip (Alessi \& Trollip, 2001). The development model of Allessi and Trollip includes three steps consisting of planning, design, and development. Evaluation on the learning multimedia development model is directly in three stages, namely the Alpha Testing, Beta Testing, and program validation.

The research was conducted at SMP Nurul Jadid Paiton. The study began on November 24, 2018 until January 20, 2019. The subjects of the research trial were students of SMP Nurul Jadid Paiton class VIII E and F. The number of test subjects was each student in 1 class. The details are class VIII E totaling 33 students for beta testing activities and class VIII F totaling 34 students for program validation activities (pretest, product trial, and posttest).

The steps in this research include: the planning, design, and development stages. The planning stage, namely: identifying the field / scope of the recount text material, identifying student characteristics, identifying technical needs, gathering and determining sources, and conducting initial idea discussions. The design phase is: making a flowchart, making a storyboard, and preparing scripts. The development phase includes: preparing text, color, images, audio and video, combining parts in the Adobe Flash CS 5 program, evaluating with Alpha testing, evaluating with Beta testing, producing the final product, and program validation.

The type of data in this study is the type of quantitative data obtained from a questionnaire that has been given to media experts, material experts, and grade VIII students of SMP Nurul Jadid Paiton. Quantitative data is converted into qualitative data. Data extracted in this study are as follows. First is the accuracy of the material for the achievement of learning competencies in SMP Nurul Jadid Paiton. The aspects studied are aspects of learning and aspects of content. Data obtained by questionnaire from material experts.

Second is the accuracy of the design of multimedia learning software. The aspects studied are aspects of appearance and programming aspects. Data obtained by questionnaire from media experts. Third is a feasible aspect of multimedia learning. Data obtained by questionnaire from students.

Data collection during the process of developing multimedia English learning for recount text learning using observation, interviews, questionnaires and tests. The instrument used in collecting data in the form of an assessment instrument to assess products that have been developed from the instructional aspect, the content aspect, the display aspect, the programming aspect. To find out the assessment of students in depth on multimedia learning products developed, the researchers used an assessment instrument from the learning aspects, material aspects, and display aspects. Before an assessment instrument is given, the instrument is validated beforehand by an expert validator.

The results of this research are in the form of responses from material experts, media experts, and students about the quality of products that have been developed in terms of learning aspects, material aspects, and media aspects. Data in the form of comments, revised suggestions, and observations of researchers during the trial process were analyzed descriptively qualitatively, and concluded as input to improve or revise products that have been developed. Whereas the data in the form of responses from material experts, media experts, and students obtained from questionnaires were analyzed descriptively quantitatively using categorization techniques that refer to the formula references from (Sukardjo and Sari, 2008) 


\section{VOL. 01 NO. 01, DECEMBER 2019}

Data obtained from questionnaires about student responses were converted into interval data with the following criteria: $1=$ very less; $2=$ less; $3=$ enough; $4=$ good; and $5=$ very good. In the questionnaire were given five choices to provide responses to the resulting multimedia product. If students, material experts, and media experts respond "very well" to the statement given, the score of the statement is "5". The scores obtained were then converted to five scale qualitative data in Table 1.

Table 1. Assessment criteria

\begin{tabular}{|c|c|c|c|}
\hline Nilai & Rumus & Perhitungan & Kriteria \\
\hline 5 & $\mathrm{X}>{ }^{-} \mathrm{i}+1,8 \mathrm{SBi}$ & $X>4,08$ & $\begin{array}{l}\text { Very } \\
\text { Good }\end{array}$ \\
\hline 4 & ${ }^{-}+0,6 \mathrm{SBi}<\overline{\mathrm{X}} \leq \mathrm{i}+1,8 \mathrm{SBi}$ & $3,36<X \leq 4,08$ & Good \\
\hline 3 & ${ }^{-}+0,6 \mathrm{SBi}<\overline{\mathrm{X}} \leq \mathrm{i}+0,6 \mathrm{SBi}$ & $2,64<X \leq 3,36$ & Enough \\
\hline 2 & ${ }_{\mathrm{i}}-1,8 \mathrm{SBi}<\overline{\mathrm{X}} \leq \mathrm{i}-0,6 \mathrm{SBi}$ & $1,92<X \leq 2,64$ & Less \\
\hline 1 & $\mathrm{X} \leq \mathrm{i}-1,8 \mathrm{SBi}$ & $X \leq 1,92$ & $\begin{array}{l}\text { Very } \\
\text { less }\end{array}$ \\
\hline
\end{tabular}

Data analysis of the results of this test is data obtained from students after being given a pretest and posttest questions about learning products that aim to determine the effectiveness of the product in the form of mastery of recount text material that is realized in the test scores of learning outcomes after using multimedia learning products that have been developed . Student learning outcomes obtained from the pretest and posttest were then analyzed by comparing the pretest score and the posttest score. Improved learning outcomes that occur before and after using multimedia, are calculated by the formula (N-gain) which is determined based on the average normalized score gain $(\mathrm{g})$, which is the ratio of the gain score. The gain score is the score obtained by students from the pretest and posttest while the maximum gain score is the highest gain score obtained by students. The normalized gain (N-gain) (Hake, 1998) is expressed by the equation as follows:

$$
g=\frac{S \text { post }-S \text { pre }}{\text { S maks }- \text { S pre }}
$$

Explanation :

$\mathrm{G}$ : Normalized average score gain

S post : Average Postes Score

S pre : Average Pretest Score

S maks : Maximal Score

Values that have been obtained are then interpreted in the Gain value classification table (Hake, 1998, p. 3) with the following criteria:

Table 2. Classification Score Gain.

\begin{tabular}{ll}
\hline Score & Classification \\
\hline$(\mathrm{N}-$ gain $) \geq 0,7$ & High \\
$0,7>(\mathrm{N}-$ & Medium \\
gain $) \leq 0,3$ &
\end{tabular}


$(\mathrm{N}-$ gain $) \leq 0,3 \quad$ Low

\section{FINDINGS AND DISCUSSION}

The planning phase starts with identifying the field or scope of the recount text material. This stage is carried out by identifying the Competency Standards and Basic Competencies in the syllabus of English subject material for grade VIII about recount text. The syllabus is used as a reference in the learning process as outlined in the multimedia learning product.

Identification of the characteristics of SMP class VIII students was carried out by conducting interviews with 1 teacher of English studies and survey subjects in class VIII E students at SMP Nurul Jadid Paiton using a questionnaire and observation. An interview with 1 teacher of English studies was conducted on November 9, 2018, while questionnaire and observation were given to 23 students of class VIII E SMP Nurul Jadid Paiton held on March 29, 2019. Interviews and survey aims to find out the problems experienced by students in understanding English recount text material. The results of the survey show that learning English recount text material using computer multimedia is desired by students. Students want the use of video, audio, background music (backsound), images that support the material, and color in learning English recount text material. The results of the survey show that students like the colors blue, red, pink (pink), black, white, green, brown, silver (silver), purple. A summary of the number of students and the types of colors that students like can be seen in Table 3 as follows.

Table 3. Number of students and the types of colors

\begin{tabular}{clc}
\hline No & \multicolumn{1}{c}{$\begin{array}{c}\text { The Color } \\
\text { Students Like }\end{array}$} & $\begin{array}{c}\text { Total } \\
\text { students }\end{array}$ \\
\hline 1. & Blue & 13 \\
2. & Red & 4 \\
3. & Pink & 2 \\
4. & Black & 7 \\
5. & White & 2 \\
6. & Green & 3 \\
7. & Brown & 1 \\
8. & Silver & 1 \\
9. & Purple & $\underline{1}$ \\
\hline
\end{tabular}

In making multimedia learning that is developed not all colors that are liked by students are included. The colors that students like are selected and sorted, then added with yellow to match the color theory in chapter two.

Identification of technical needs includes the use of hardware and software. These tools are used to process three-dimensional and two-dimensional images (3D and 2D), sound, and video in the process of developing the developed learning media. The hardware used includes Intel $®$ Pentium ${ }^{\circledR}$ Dual CPU E2140 @ 1.60 GHz, 4GB Memory, screen resolution of 1024x768 pixels, Sound card, VGA Radeon HD 7730. Software used includes Microsoft Windows 7 Ultimate, Adobe Flash CS5, Makehuman 1.0.0 , 3ds Max 2008, Blender 2.67, Camtasia Studio 8, Adobe Audition CS5.5, Adobe Illustrator CS3, Adobe Photoshop CS4.

Literature study is needed to collect and determine sources. Literature study was conducted to gather information, by studying the syllabus of English subjects for class VIII in semester 1 relating to the characteristics of the subjects, available time allocations, then reading books on English subjects, and questions related information obtained through the Internet. The books used are books titled English in Focus for Grade VIII Junior High Schools (SMP / MTs) and books titled Super Smart Materials and Daily Tests for SMP / MTs Grade 8. 


\section{VOL. 01 NO. 01, DECEMBER 2019}

Initially the discussion of ideas was conducted with a teacher of English language subject VIII at SMP Nurul Jadid Paiton. Then the results of the discussion are examined before starting the process of making learning multimedia. Discussions with teachers of English subjects were conducted during the interview, which was on November 9, 2018.

After the planning stage has been carried out, then the design phase is carried out with the aim of making it easier to create a multimedia learning program that is developed. At this stage there are steps in the activity of making flowcharts, making story-boards, preparing scripts for explanatory video narratives.

Multimedia learning products developed using Adobe Flash CS5 with the target user for class VIII students. The multimedia production process that is developed is processed using the Adobe Flash CS 5 program supported by other programs such as Makehuman 1.0.0, 3ds Max 2008, Blender 2.67, Camtasia Studio 8, Adobe Audition CS5.5, Adobe Illustrator CS3, and Adobe Photoshop CS4. Ongoing evaluation is carried out to evaluate whether the developed multimedia learning product is working properly or not. Activities carried out at the development stage are preparing text, colors, images, audio and video, combining all parts or materials that have been prepared into Adobe Flash CS5 by adjusting the flowchart and storyboard.

After the developed learning multimedia has been assessed by two material experts, two media experts, and students, the final product is ready to be used by students. The main slide shows contained in the product being developed include picture 1. Display screen on the title page, and picture 2. Display screen on the main menu.

Picture 1. Display screen on the title page

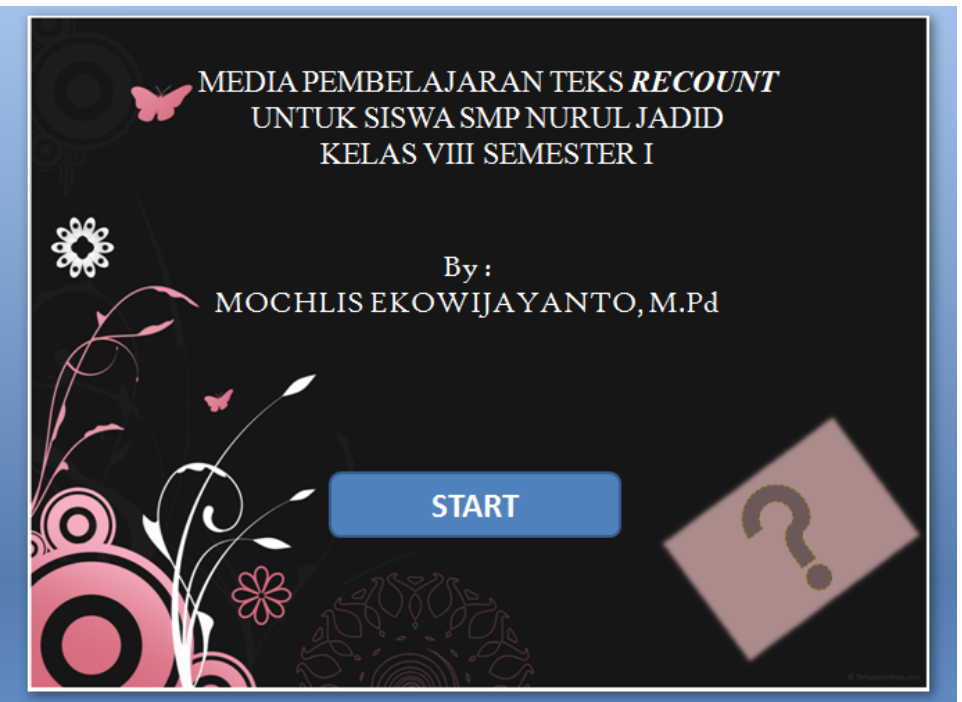

Alpha Testing Results

In analyzing the results of the evaluation of the material expert product I, there are two aspects that become the expert judgment of material I, namely the learning aspect and the content aspect. Data analysis of the results of the assessment of the material expert product I is based on the material expert assessment phase II. In the learning aspect there are 16 assessment indicators, 10 indicators get a score of 5 (Very Good), 6 indicators get 4 (Good). The results of the calculation of the mean score on the learning aspect are 4.62 with the Very Good category. In the aspect of content there are 11 assessment indicators, with details 8 indicators get a score of 5 (Very Good) and 3 indicators get a score of 4 (Good). The average aspect of this content is 4.72 with the Very Good category.

The results of the assessment by the material expert I can be seen in the summary of the results of the material expert assessment I Table 4. 
Table 4. Results of Expert Material Assessment I

\begin{tabular}{|c|c|c|c|}
\hline No & $\begin{array}{l}\text { Assessment } \\
\text { aspects }\end{array}$ & Average & Categori \\
\hline 1 & Learning & 4,62 & Very Good \\
\hline 2 & Content & 4,72 & Very Good \\
\hline Total & & 4,67 & Very Good \\
\hline
\end{tabular}

Range 1-5

The aspects that become the expert judgment on material II in the analysis of the results of the evaluation of the expert material II are the learning aspects and the content aspects. In the learning aspect there are 16 assessment indicators. 3 indicators get a score of 5 (Very Good) and 13 assessment indicators get a score of 4 (Good). The mean of this learning aspect is 4.18 with the Very Good category. In the aspect of content there are 11 assessment indicators, with details 6 indicators get a score of 5 (Very Good) and 5 indicators get a score of 4 (Good). The average aspects of this content aspect is 4.54 in the Very Good category. The total of the two aspects assessed was in the category of Very Good with a total of 117 and an average of 4.36. The results of the expert judgment on material II can be seen in the summary of the results of the expert judgment on material II Table 5.

Table 5. Results of Expert Material Assessment II

\begin{tabular}{llll}
\hline No & $\begin{array}{c}\text { Assessment } \\
\text { aspects }\end{array}$ & Average & Categori \\
\hline 1 & Learning & 4,18 & Very Good \\
2 & Content & 4,64 & Very Good \\
& Total & 4,36 & Very Good \\
\hline
\end{tabular}

Range 1-5

In the analysis of the results of the evaluation of media expert I, there are two aspects that become the evaluation of media expert I, namely the aspect of media appearance and programming aspects. In the aspect of media display, there are 14 assessment indicators. 2 assessment indicators get a score of 5 (Very Good), 11 assessment indicators get a score of 4 (Good) and 1 assessment indicator gets a score of 3 (Enough) with a mean score on that aspect is 4.07 with the Good category. In the programming aspect there are 10 assessment indicators with details 6 assessment indicators get a score of 5 (Very Good), 3 assessment indicators get a score of 4 (Good) and 1 assessment indicator gets a score of 3 (Enough) with a mean score on that aspect is 4.50 with Very Good category. The total of the two aspects assessed was 102 and 4.28 with the Very Good category. The results of the assessment of media experts can be seen in the summary of the results of the assessment of media experts I Table 6.

Table 6. Results of Media Expert I

\begin{tabular}{llll}
\hline No & $\begin{array}{c}\text { Assessment } \\
\text { aspects }\end{array}$ & Average & Categori \\
\hline 1 & Media Display & 4,07 & Good \\
2 & Programming & 4,50 & Very Good \\
& Total & 4,28 & Very Good \\
\hline
\end{tabular}

Range 1-5

The assessment of media experts II covers the quality of the product developed, reviewed from two aspects, namely the aspect of media appearance and programming aspects. There are 14 indicators of media display aspects. All of these indicators received a score of 4 


\section{VOL. 01 NO. 01, DECEMBER 2019}

(Good) with an average score in that aspect being 4.00 in the Good category. In the programming aspect there are 10 assessment indicators with details of 6 items getting a score of 5 (Very Good) and 4 items getting a score of 4 (Good). The result of the average score calculation in the programming aspect is 4.60 with the category of Very Good. The overall total of the aspects assessed received a Very Good category with a total of 102 and a mean of 4.30. The results of the assessment by media experts II can be seen in the summary of the results of the assessment of media experts II Table 7.

Table 7. Results of Media Expert II

\begin{tabular}{llll}
\hline No & $\begin{array}{c}\text { Assessment } \\
\text { aspects }\end{array}$ & Average & Categori \\
\hline 1 & Media Display & 4,00 & Good \\
2 & Programming & 4,60 & Very Good \\
& Total & 4,30 & Very Good \\
\hline
\end{tabular}

Range 1-5

Beta Test Results (Beta Testing)

The aspects that students assess in beta testing are aspects of learning, material aspects, and display aspects. The results of student assessment in this test indicate that of the 12 indicators assessed by 30 students of VIII E SMP Nurul Jadid Paiton obtained an Excellent category for the learning aspect with a mean of 4.20, a Very Good category for the material aspect with a mean of 4.28, and an Excellent category for the aspect display with an average of 4.10. The results of the summary assessment by students on beta testing (beta testing) can be seen in Table 8.

Table 8. Beta Test Result

\begin{tabular}{llll}
\hline No & $\begin{array}{c}\text { Assessment } \\
\text { aspects }\end{array}$ & Average & Categori \\
\hline 1 & Learning & 4,20 & Good \\
2 & Materials & 4,28 & Very Good \\
3 & Display & 4,10 & Very Good \\
& Total & 4,19 & Very Good \\
\hline
\end{tabular}

Value Range 1-5

The student assessment of the learning multimedia product developed obtained a sum of the mean scores of 4.19. Thus the developed multimedia learning products can be declared very good and feasible to be used in learning English for learning recount text material at SMP Nurul Jadid Paiton.

Program Validation Results

Product Trial Results

The product trial was carried out with 34 students from class VIII E at SMP Nurul Jadid Paiton computer subject. Questionnaire sheets are provided after students use the developed learning multimedia products. Product trials are conducted 4 hours or 4 times 40 minutes. The first and second class hours were held on Tuesday 6 January 2019 at 7 or 11.35 before the break and 9 or 12.55 after the break. The third and fourth class hours are held on Tuesday January 20 2019 at 5 o'clock or 10.15 o'clock and at 6 o'clock or 10.55 o'clock. The results of student assessment on the questionnaire sheet can be seen in Table 9.

Table 9. Student Assessment Results on Product Trial 


\begin{tabular}{llll}
\hline No & $\begin{array}{c}\text { Assessment } \\
\text { aspects }\end{array}$ & Average & Categori \\
\hline 1 & Learning & 3,92 & Good \\
2 & Materials & 4,05 & Good \\
3 & Display & 3,80 & Good \\
& Total & 3,92 & Good \\
\hline
\end{tabular}

Value Range 1-5

There are 3 aspects that become the assessment of learning multimedia products that are developed, namely learning aspects amounting to 3 indicators, material aspects amounting to 4 indicators, and display aspects amounting to 5 indicators. The table above shows that students gave a positive value or good category to the statements given by obtaining an average of 3.92 from the 3 aspects assessed. In the learning aspect the total value obtained is 389 with an average of 3.92 in the Good category. In the material aspect with 4 indicators given the total score obtained is 536 with an average of 4.05 and has Good criteria. In the aspect of appearance, student assessment based on Table 9 obtained a total score of 628 with an average of 3.80 .

Learning Outcomes (Pretest and Posttest)

Pretest and posttest were conducted to determine the effectiveness of multimedia learning products developed in improving student learning outcomes for recount text material. Changes in learning outcome scores are calculated using standard gain techniques, ie an increase in scores is obtained from the final score (posttest) minus the initial score (pretest) then divided by the result of the reduction between the maximum score and the initial score (pretest). The product effectiveness criteria are determined based on the results of the students' pretest and posttest in terms of the average number of gain score indexes of all grade VIII E students taking the pretest and posttest tests.

A total of 28 students ( $88 \%$ ) were included in the high category while 3 students (9\%) were in the medium category, and 1 student $(3 \%)$ was in the low category. Based on the classification table of the gain values obtained, the effectiveness of the products developed is included in the high classification of $0.90(\mathrm{~N}$-gain $\geq 0.7)$ as seen from the average number of gain scores for all grade VIII students $\mathrm{E}$ who took the pretest and posttest. The diagram of obtaining a student gain classification can be seen in Picture 3.

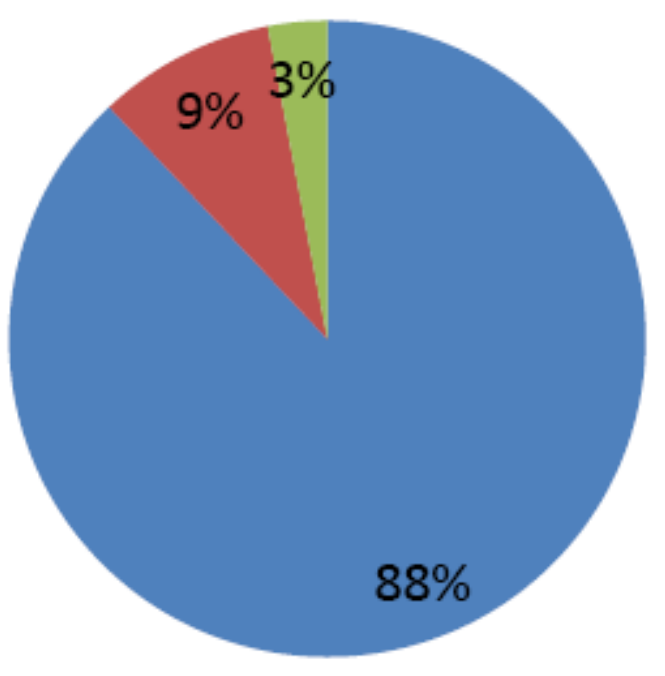
High Category
Medium category
Low Category 
VOL. 01 NO. 01, DECEMBER 2019

Picture 3. Classification of Student Gain Score

\section{Discussion}

Multimedia learning English product for recount text learning created using Adobe Flash CS5 software and other supporting software is one of the complementary learning resources that aims to facilitate students enriching the vocabulary of English in the recount text material, making it easier for students to arrange a series of events in the form of random paragraphs from the recount text, and makes it easier for students to understand changes in past verb forms in the recount text. Multimedia learning products developed using seven principles from 12 principles (Mayer, 2002).

The seven principles are the principle of coherence, the principle of signaling, the principle of space closeness, the segmenting principle, the pre-training principle, the multimedia principle, and the personalization principle. The form of applying the principle of coherence to the developed multimedia is the use of picture bars that correspond to the meaning of each sentence in each recount text paragraph. The form of applying the principle of giving a sign or signaling is the giving of a yellow mark to each word that serves to find out the meaning of each word by directing the mouse arrow on the signs. The form of the application of the principle of the proximity of space is the closeness between the sentences in the recount text paragraph and the images associated with these sentences on 1 screen. The application of the principle of cutting (segmenting) in multimedia learning that is developed is that each video is divided into six different themes and not a full video.

This principle also applies to recount text forms divided into three paragraphs so that students can easily find out the meaning of each sentence in those paragraphs. The form of the application of the principle of pre-training in multimedia learning that is developed is the use of video to explain the characteristics of the main concepts of recount text material such as understanding recount text, the purpose of recount text, generic recount text structure and recount text characteristics that are includes the use of subject pronoun, sequence words, and simple past tense. The application of multimedia principles is in the use of pictures and words in each paragraph of the recount text. The form of the application of the principle of personalization in multimedia learning that is developed is the command sentences that use the language of conversation and not formal language. Multimedia technology teaching has exclusively motivated students' positive thinking and communication skills in a social simulated practice (Ghanizadeh \& Razavi, 2015).

The developed multimedia is based on several theories of learning and language learning, namely behavioristic, cognitive, and constructivistic. First of all, behaviour is composed of reactions and movements that an organism gives and does in a certain situation. The term, behaviour is mostly used for actions that can be observed from outside. Behaviorist learning approach mostly focuses on how behaviours are acquired. Behaviorist approach claims that learning can develop by means of establishing a connection between stimulus and behaviour, and that any behaviour can be changed through reinforcement (Bacanl1, 2016). The form of application to readiness in English multimedia products about recount text material is on the setting of competency standards, basic competencies, and indicators to be achieved.

Cognitive development is a comprehensive theory about the nature and development of human intelligence. The theory deals with the nature of knowledge itself and how humans gradually come to acquire, construct, and use it. Cognitive development is at the center of the human organism, and language is contingent on knowledge and understanding acquired through cognitive development (Piaget, 2002). Cognitive theory in this study is applied to example sentences. The application of limited capacity assumptions is found in English sentences which are cut into small parts of words, then the pieces of words can be accessed by students making it easier for students to compile the Indonesian meaning of the English sentence in full. Short 


\section{VOL. 01 NO. 01, DECEMBER 2019}

duration material videos provide students with preliminary knowledge about the rules of paragraph formation, the use of sequence words, and the use of past verbs and auxiliary verbs in a recount text.

Constructivism has emerged in recent years as a dominant paradigm in education and has had a major intellectual impact on the development of pedagogy, rooted in the cognitive developmental of Piaget and in the sociocultural theory of Vygotsky, constructivist notions have had an impact on the development and application of technologically enhanced micro worlds and on linguistic investigation into literacy and narrative development constructivist learning has developed as a substantial approach to teaching (Muna Aljohani, 2017). The constructivist theory in this study was applied to the selection of pieces of words and sentences in the examples of recount text examples. Students' knowledge about the shape and use of sequence words, verbs and verbs of auxiliary past will be formed through the process of student interaction with the presentation of pictures, example sentences and word pieces, the more they interact with the example the more detailed are their own knowledge and understanding of the material.

Multimedia products are developed using music as a background because music has the benefit of entertaining, bringing a relaxed atmosphere when learning takes place, and positively influencing emotions. The benefits of music have been extensively discussed from its aesthetic value to its therapeutic, cultural, social, and pedagogical features in the field of SLA and cognitive science (Romero TESOL, 2017).

After alpha testing (assessment conducted by two material experts and two media experts), beta testing, and product testing on program validation it is proven that the use of multimedia learning about recount text material developed effectively can improve student learning outcomes. From the results of the pretest and posttest conducted an increase in student grades.

The quality of multimedia products developed can be classified as very good or very good. This is evidenced from the comments obtained through student questionnaires on beta tests and product trials. Students in the beta test and product trial give comments in the form of the impression that the multimedia learning products developed are interesting, fun and make it easy for them to understand recount text material.

Multimedia learning products developed have several advantages as well as having shortcomings and limitations that must be considered. The advantages of multimedia learning products developed are able to save learning time, motivate students to learn English about recount text material, make it easier for students to learn English recount text material. The weakness of the product being developed is that the questions contained in the multimedia learning program developed cannot be updated by the teacher. Multimedia learning products developed do not have quiz questions that are randomized automatically. The product developed is only designed for writing skills. With this developed learning multimedia product it is expected to be one of the complementary learning resources that can help solve learning problems in recount text material.

\section{CONCLUSION}

The product developed is feasible to be used as one of the complementary learning resources in terms of expert assessment of material I on the learning aspect which obtains an average score of 4.62 with the Very Good category and the content aspect which obtains an average rating of 4.72 with the Very category Well. Material expert assessment II on the learning aspect gained an average value of 4.18 in the Very Good category and the content aspect obtained an average grade of 4.54 in the Very Good category. The evaluation of media expert I on the aspect of media display obtained an average score of 4.07 with the Good category 
and the programming aspect obtained an average score of 4.50 with the Very Good category. Assessment of media experts II on the aspect of media display get an average value of 4.00 in the Good category and programming aspects get an average value of 4.60 in the Very Good category. Beta test results get an average value of 4.19 in the Very Good category . The product trial results obtained an average value of 3.92 in the Good category. The increase in the average gain score of all students from the pretest and posttest results was 0.90 ( $\mathrm{N}$-gain $\geq 0.7$ ). This means that the effectiveness of the product being developed is in the high category.

The use of multimedia English learning programs for recount text learning is effective if the teacher uses it in the right way. Suggestions for use in using a multimedia learning program that is the teacher explains to students about the program and its use in order to make it easier for students to understand the material presented. The teacher can utilize this learning multimedia product after the teacher explains the recount text material in class. This product only serves as a complementary learning resource and not as a substitute for the teacher's role.

For students, so that the use of multimedia learning programs is useful and useful, they should follow the suggestions, namely students read and study the whole material in sequence starting from the instructions, Competency Standards and Basic Competencies (SK and KD), material, summary, quiz, and evaluation. Discuss with the teacher or peers if there are difficulties in running the program or material that is not understood. Students should pay attention to the instructions in the program so students can operate the program easily. 
VOL. 01 NO. 01, DECEMBER 2019

\section{REFERENCES}

Alessi, S. M., \& Trollip, S. R. (2001). Multimedia for learning: Methods and development. Allyn \& Bacon.

Bacanl, H. (2016). Learning and Teaching: Theories, Approaches and Models Chapter 2: Behaviorist Approach. Learning and Teaching: Theories, Approaches and Models, 112. Retrieved from http://www.ijonte.org/FileUpload/ks63207/File/chapter_2.pdf

Baidawi, A. (2016). OKARA Journal of Languages and Literature, Vol . 1, Tahun 1 , Mei 2016 OKARA Journal of Languages and Literature, Vol . 1, Tahun 1, Mei 2016. OKARA Journal of Languages and Literature, 1(1), 54-65.

Curir, A., de Romeri, V., \& Murante, G. (2010). Evolution and instabilities of disks harboring super massive black holes. Astrophysics and Space Science, 327(2), 259-266. https://doi.org/10.1007/s10509-010-0328-8

D'Arcy Nell, D. (2017). English language teaching. In History of Oxford University Press: Volume IV 1970 to 2004. https://doi.org/10.1093/acprof:oso/9780199574797.003.0018

Ezennia, I., Agbonome, P., Uwajeh, P., \& Iyendo, T. (2016). The benefits of digital multimedia as a teaching and learning aid in architectural design studios. International Journal of Current Research, 8(9), International Journal of Current Research. Retrieved from https://www.researchgate.net/publication/309040003_The_benefits_of_digital_multimed ia_as_a_teaching_and_learning_aid_in_architectural_design_studios

Ghanizadeh, A., \& Razavi, A. (2015). The impact of using multimedia in English high school classes on students' language achievement and goal orientation. International Journal of Research Studies in Educational Technology, 4(2), 31-42. https://doi.org/10.5861/ijrset.2015.1183

Hake, R. R. (1998). Interactive-engagement versus traditional methods: A six-thousandstudent survey of mechanics test data for introductory physics courses. American Journal of Physics, 66(1), 64-74. https://doi.org/10.1119/1.18809

Harmer, J. (1991). The practice of English language teaching. London/New York, 201.

Mayer, R. E. (2002). Multimedia learning. Psychology of Learning and Motivation Advances in Research and Theory, 41, 85-139. https://doi.org/10.5926/arepj1962.41.0_27

Muna Aljohani. (2017). Principles of "Constructivism" in Foreign Language Teaching Journal of Literature and Art Studies, 7(1), 97-107. https://doi.org/10.17265/21595836/2017.01.013

Patel, M. F., \& Jain, P. M. (2008). English language teaching. Sunrise Publishers and Distributors.

Piaget, J. (2002). The language and thought of the child (Vol. 5). Psychology Press.

Romero TESOL, P. X. (2017). Teaching and Learning English through Songs: A Literature Review. MSU Working Papers in SLS, 8(2008), 40-45.

Sukardjo \& Sari, L. P. (2008). Penilaian hasil belajar Kimia. Yogyakarta: Universitas NegeriYogyakarta. 